\title{
PENGARUH MACAM AMELIORAN DAN TARAF DOSIS LOGAM BERAT TERHADAP PH, CR TOTAL TANAH, SERAPAN CR SERTA HASIL TANAMAN SELADA (Lactuca sativa L.) PADA ANDISOLS LEMBANG
}

\author{
Yondra Saputra, Anne Nurbaity, Oviyanti Muryani \\ Fakultas Teknik Universitas Muhammadiyah Riau \\ Email: ridwanabrar@yahoo.com
}

\begin{abstract}
ABSTRAK
Pencemaran tanah oleh logam berat dapat menurunkan produktivitas tanah. Untuk itu perlu dicari alternatif solusi untuk menanggulangi dampak negatif dari logam berat. Percobaan ini bertujuan untuk mengetahui pengaruh macam amelioran dandosis $\mathrm{Cr}$ terhadap $\mathrm{pH}, \mathrm{Cr}$ total tanah, serapan $\mathrm{Cr}$ dan hasil tanaman selada (Lactuca sativa $\mathrm{L}$ ) pada Andisols asal Lembang. Percobaan dilaksanakan di rumah kaca dengan ketinggian tempat $\pm 700 \mathrm{~m}$ dpl dari Mei sampai dengan Juli 2010.

Rancangan penelitian yang digunakan adalah Rancangan Acak Kelompok (RAK) pola faktorial, dengan dua kali ulangan. Faktor pertama yaitu macam amelioran, terdiri atas lima taraf: tanpa amelioran (kontrol), kompos serasah daun jagung, arang sekam, zeolit dan dolomit. Sedangkan faktor kedua yaitu dosis Cr, terdiri atas empat taraf: $\mathrm{Cr} 0$ ppm, 15 ppm, 30 ppm, 45 ppm.

Hasil percobaan menunjukkan bahwa terjadi interaksi antara macam amelioran dan dosis Cr terhadapCr total tanah dan serapan $\mathrm{Cr}$, akan tetapi tidak terjadi interaksi terhadap $\mathrm{pH}$ tanah dan hasil selada. Amelioran terbaik dalam meningkatkan $\mathrm{pH}$ tanah dan menurunkan serapan $\mathrm{Cr}$ oleh tanaman serta memberikan rata-rata hasil tanaman selada terbaik adalah dolomit, sedangkan amelioran terbaik yang mampu menurunkan rata-rata $\mathrm{Cr}$ total tanah hingga 69,5 ppm adalah arang sekam. Hasil penelitian secara umum memperlihatkan bahwa dolomit lebih baik digunakan untuk memperkecil serapan $\mathrm{Cr}$ sebesar 0,006 ppb, meningkatkan pH hingga 5,21 dan hasil tanaman sebesar 41,6 gr polibeg ${ }^{-1}$ yang ditanam pada tanah tercemar logam berat $(\mathrm{Cr})$.
\end{abstract}

Kata Kunci: amelioran, logam berat $\mathrm{Cr}$, tanaman selada

\section{PENDAHULUAN}

Peningkatan hasil pertanian harus disertai kualitas yang baik serta memiliki tingkat keamanan yang tinggi untuk dikonsumsi. Akan tetapi, meningkatnya kegiatan manusia di muka bumi, dapat menimbulkan berbagai polusi, baik itu polusi udara, air, maupun tanah. Salah satu polusi tanah yang disebabkan dari berbagai kegiatan manusia adalah pencemaran yang disebabkan oleh penimbunan logam berat (Nanik, 2008).

Salah satu logam berat yang menjadi polutan dan mencemari tanah jika terdapat dalam jumlah yang besar adalah kromium (Cr). Kromium dapat berasal dari berbagai kegiatan manusia, diantaranya yaitu kegiatan pewarnaan kain, industri tekstil, cat, penyamakan kulit, pelapisan logam, baterai atau industri krom (Nanik, 2008).

Bertambahnya tumpukan $\mathrm{Cr}$ pada tanah menyebabkan siklus hara di dalam tanah terganggu dan akhirnya kesuburan tanah menurun. Di dalam tanah $\mathrm{Cr}$ terdapat dalam bentuk $\mathrm{Cr}^{3+}$ yang bersifat stabil serta dalam bentuk $\mathrm{Cr}^{6+}$ yang bersifat labil dan berbahaya (Nanik, 2008). Kondisi oksidasi dan bentuk $\mathrm{Cr}$ di dalam tanah tergantung pada kondisi lingkungan tanah, $\mathrm{Cr}^{6+}$ akan banyak terbentuk pada kondisi $\mathrm{pH}$ masam. Tanah dikatakan telah tercemar oleh $\mathrm{Cr}$ jika konsentrasinya terdapat antara 10 hingga 90 ppm di dalam tanah (Bruce, 2002), sedangkan batas kritis tanah tercemar oleh $\mathrm{Cr}$ yaitu antara $75 \mathrm{ppm}$ hingga $100 \mathrm{ppm}$ (Alloway, 1990).

Kandungan logam berat dalam tanah berkorelasi positif dengan kandungan logam berat dalam tanaman yang tumbuh pada lahan tercemar logam berat (Subowo et al., 1994). Terserapnya $\mathrm{Cr}^{6+}$ oleh tanaman secara tidak langsung akanmempengaruhi kualitas tanaman, karena melalui rantai makanan $\mathrm{Cr}$ dapat 
terdeposit dalam bagian tubuh mahluk hidup dan dalam jumlah tertentu akanmenyebabkan racun bagi tubuh makhluk hidup. Konsumsi kromium yang dapat ditoleransi bagi tubuh manusia maksimum 0,07 ppm perhari (Nanik, 2008). Akumulasi $\mathrm{Cr}$ di dalam tubuhmanusia dapatmenyebabkan

kerusakan terhadaporganrespirasi, dan menyebabkan timbulnya kanker pada manusia (Palar, 1994).

Hasil survei menunjukkan bahwa beberapa sayuran di Jawa Barat diketahui mengandung logam berat seperti timbal $(\mathrm{Pb})$ dan cadmium (Cd) pada umbi kentang dan wortel yang melebihi ambang batas (Nurfindarti, 2004). Logam $\mathrm{Cr}$ ditemukan pula terkandung di dalam tanaman yang dibudidayakan di daerah pembuangan limbah tekstil di Jawa Barat (Sudirja, 1999). Jika hasil pertanian tersebut dikonsumsi dalam jumlah yang banyak, akan menyebabkan keracunan.

Upaya yang dapat dilakukan untuk mengurangi serapan logam berat oleh tanaman adalah dengan pemberian amelioran. Amelioran dapat berupa bahan organik seperti kompos, pupuk kandang, abu kayu, arang sekam, arang aktif dan ampas tebu, maupun bahan anorganik seperti dolomit, gipsum, bitumen, zeolit, kaolinit (Hartatik et al., 2008).

Amelioran organik seperti kompos dapat mengurangi pengaruh buruk yang ditimbulkan oleh logam berat $\mathrm{Cr}$ dan mempertahankan tanaman dalam keadaan normal (Cahyati, 2000). Senyawa organik pada kompos daun jagung seperti asam humat dan asam fulvat mampu membentuk senyawa kompleks dengan ion-ion logam sehingga dapat mengurangi serapan logam oleh tanaman (Tan, 1995). Selain kompos daun jagung, amelioran organik seperti abu sekam juga dapat digunakan sebagai amelioran karena bersifat absorben terhadap logam serta memiliki kemampuan dalam meningkatkan $\mathrm{pH}$ tanah (Winarti et al., 1997).

Amelioran anorganik yang mampu memperkecil tingkat keracunan oleh logam berat antara lain zeolit dan dolomit. Strukturkerangkaaluminosilikat pada zeolit memungkinkan terjerapnya $\mathrm{Cr}$ dalam polihedralnyasehinggamemperkecil
konsentrasiCrterlarutdanCrmenjaditidaktersedia bagitanaman (Cahyati, 2000). Demikian pula dolomit, kemampuannya meningkatkan $\mathrm{pH}$ tanah, menyebabkan perubahan sifat logam berat (Winarti et al., 1997). Meningkatnya $\mathrm{pH}$ ke arah netral, akan mengubah bentuk $\mathrm{Cr}^{6+}$ menjadi $\mathrm{Cr}^{3+}$ sehingga $\mathrm{Cr}$ bersifat stabil dan tidak tersedia bagi tanaman (Bruce, 2002).

Akumulasi logam oleh tanaman tidak hanya tergantung pada ketersediaan logam tersebut di dalam tanah, tetapi juga tergantung pada jenis tanaman. Selada merupakan tanaman yang bersifat akumulator dan memiliki kemampuan hidup pada kondisi tanah yang tercemar, karena lebih mampu menyerap kontaminan seperti logam berat dibandingkan dengan tanaman sayuran lain (Haghiri, 1973).

Pemberian amelioran organik maupun anorganik diharapkan mampu menurunkan serapan logam $\mathrm{Cr}$ oleh selada. Oleh karena itu perlu dilakukan penelitian untuk mengetahui pengaruh macam amelioran terhadap $\mathrm{pH}$ tanah, $\mathrm{Cr}$ total tanah, serapan $\mathrm{Cr}$ serta hasil tanaman selada pada Andisols Lembang yang diberi berbagai dosis logam berat $\mathrm{Cr}$.

\section{METODOLOGI PENELITIAN}

\section{Tempat dan Waktu Peneitian}

Penelitian ini dilaksanakan dari bulan Mei 2010 hingga Juli 2010. Penanaman dilakukan di rumah kaca Fakultas Pertanian Universitas Padjadjaran Jatinangor, Kabupaten Sumedang Jawa Barat dengan ketinggian $\pm 700 \mathrm{~m}$ di atas permukaan laut. Sedangkan analisis dilaksanakan di Laboratorium Kesuburan Tanah Jurusan Ilmu Tanah Fakultas Pertanian Universitas Padjadjaran dan Pusat Penelitian Teknologi Mineral dan Batu Bara (PPTM),Bandung.

\section{Bahan dan Alat}

Bahan-bahan yang akan digunakan dalam penelitian ini antara lain adalah: (1) Benih selada daun (Lampiran 1), (2) Tanah ordo Andisols lembang (hasil analisis awal terdapat pada Lampiran 2), (3) Logam berat Kromium (Cr) dalam bentuk kalium dicromat $\left(\mathrm{K}_{2} \mathrm{Cr}_{2} \mathrm{O}_{7}\right)$ (4) Kompos serasah daun jagung, (5) Arang sekam, (6) Zeolit, (7) Dolomit(8) Pupuk dasar (Urea, 
Sp-18, KCl), (9) Bahan-bahan kimia untuk analisis tanah dan tanaman di laboratorium, (10) Organisme Decomposer (OrgaDec) sebagai aktivator dalam pembuatan kompos.

Alat-alat yang akan digunakan pada percobaan adalah: (1) Cangkul dan sekop, (2) Plastik/Terpal, (3) Karung, (4) Timbangan, (5) Saringan tanah berdiameter $2 \mathrm{~mm}$, (6) Polibeg, (7) Baki (tempat untuk media semai), (8) Gunting (9) Alat penyiram, (10) Alat-alat tulis, (11) Alat-alat laboratorium untuk analisis tanah dan tanaman.

\section{RancanganPenelitian}

Rancangan Percobaan

Penelitian menggunakan Rancangan Acak Kelompok (RAK) pola faktorial dengan 2 faktor.
Faktor pertama terdiri atas lima jenis amelioran dan faktor kedua terdiri atas empat taraf dosis $\mathrm{Cr}$ dengan dua kali ulangan, sehingga diperoleh empat puluh pot percobaan.

Faktor 1: Jenis Amelioran (A) terdiri atas:

$\mathrm{a}_{0}=$ Kontrol ( Tanpa Amelioran)

$\mathrm{a}_{1}=$ Kompos Serasah Daun Jagung 10 ton $\mathrm{ha}^{-1}$ $=22$ gr polibeg $^{-1}$

$\mathrm{a}_{2}=$ Arang sekam 10 ton $\mathrm{ha}^{-1}=22$ gr polibeg ${ }^{1}$

$\mathrm{a}_{3}=$ Zeolit 1 ton ha ${ }^{-1}$ Tanah $=2,2$ gr polibeg $^{-1}$

$\mathrm{a}_{4}=$ Dolomit 4 ton $\mathrm{ha}^{-1}=8,8 \mathrm{gr}^{-1}$ polibeg ${ }^{-1}$

Faktor 2: Taraf Dosis $\mathrm{Cr}(\mathrm{T})$ terdiri atas:

$\mathrm{t}_{0}=0 \mathrm{ppm}=0$ gr polibeg $^{-1}$

$\mathrm{t}_{1}=15 \mathrm{ppm}=0,24$ gr polibeg $^{-1}$

$\mathrm{t}_{2}=30 \mathrm{ppm}=0,49$ gr polibeg $^{-1}$

$\mathrm{t}_{3}=45 \mathrm{ppm}^{2}=0,73$ gr polibeg $^{-1}$

Tabel 1. Kombinasi Perlakuan antara Amelioran dengan Dosis $\mathrm{Cr}$

\begin{tabular}{ccccc}
\hline \multirow{2}{*}{$\begin{array}{c}\text { Jenis Amelioran } \\
\text { (A) }\end{array}$} & $0 \mathrm{ppm}(\mathrm{to})$ & $15 \mathrm{ppm}\left(\mathrm{t}_{1}\right)$ & $30 \mathrm{ppm}\left(\mathrm{t}_{2}\right)$ & $45 \mathrm{ppm}\left(\mathrm{t}_{3}\right)$ \\
\cline { 2 - 5 } & $\mathrm{a}_{0} \mathrm{t}_{0}$ & $\mathrm{a}_{0} \mathrm{t}_{1}$ & $\mathrm{a}_{0} \mathrm{t}_{2}$ & $\mathrm{a}_{0} \mathrm{t}_{3}$ \\
$\mathrm{a}_{0}$ & $\mathrm{a}_{1} \mathrm{t}_{0}$ & $\mathrm{a}_{1} \mathrm{t}_{1}$ & $\mathrm{a}_{1} \mathrm{t}_{2}$ & $\mathrm{a}_{1} \mathrm{t}_{3}$ \\
$\mathrm{a}_{1}$ & $\mathrm{a}_{2} \mathrm{t}_{0}$ & $\mathrm{a}_{2} \mathrm{t}_{1}$ & $\mathrm{a}_{2} \mathrm{t}_{2}$ & $\mathrm{a}_{2} \mathrm{t}_{3}$ \\
$\mathrm{a}_{2}$ & $\mathrm{a}_{3} \mathrm{t}_{0}$ & $\mathrm{a}_{3} \mathrm{t}_{1}$ & $\mathrm{a}_{3} \mathrm{t}_{2}$ & $\mathrm{a}_{3} \mathrm{t}_{3}$ \\
$\mathrm{a}_{3}$ & $\mathrm{a}_{4} \mathrm{t}_{0}$ & $\mathrm{a}_{4} \mathrm{t}_{1}$ & $\mathrm{a}_{4} \mathrm{t}_{2}$ & $\mathrm{a}_{4} \mathrm{t}_{3}$ \\
$\mathrm{a}_{4}$ & & & \\
\hline
\end{tabular}

\section{Rancangan Respon}

Pengamatan terdiri atas pengamatan utama dan pengamatan penunjang. Pengamatan utama yang di lakukan pengujian lanjutsecara statistik, terdiri dari:

1) $\mathrm{pH}$ tanah

2) Kromium (Cr)total tanah

3) Serapan $\mathrm{Cr}$

4) Hasil tanaman selada

Sedangkan pengamatan penunjang, yang tidak dilakukan pengujian lanjut secara statistik terdiri dari:

1) Panjang akar

2) Berat kering akar

3) Jumlah Daun

\section{Rancangan Analisis}

Model Linier Rancangan Acak Kelompok menurut Gomez and Gomez (1995) yaitu sebagai berikut:

$\mathrm{Y}_{\mathrm{ijk}}=\mu+\tau_{\mathrm{i}}+\alpha_{\mathrm{j}}+\beta_{\mathrm{k}}+(\alpha \beta)_{\mathrm{jk}}+\varepsilon_{\mathrm{ijk}}$

Diketahui:

$\mathrm{Y}_{\mathrm{ijk}}=$ Pengamatan ulangan ke-i yang menerima perlakuan ke-j dan ke-k

$\mu=\quad$ Nilai rata-rata pengamatan

$\tau_{\mathrm{i}}=\quad$ Pengaruh ulangan ke- $\mathrm{i}$

$\alpha_{j}=\quad$ Pengaruh pemberian amelioran taraf ke-j

$\beta_{\mathrm{k}}=\quad$ Pengaruh pemberian dosis Cr taraf ke- $\mathrm{k}$

$(\alpha \beta)_{\mathrm{jk}}=$ Pengaruh interaksi taraf ke-j amelioran dan taraf ke-k dosis $\mathrm{Cr}$

$\varepsilon_{\mathrm{ijk}}=$ Galat 
Tabel 1. Analisis Sidik Ragam Rancangan Acak Kelompok

\begin{tabular}{|c|c|c|c|c|}
\hline $\begin{array}{l}\text { Sumber } \\
\text { Ragam }\end{array}$ & DB & JK & $\mathrm{KT}$ & Fhit \\
\hline Ulangan & $\mathrm{r}-1=1$ & $\begin{array}{l}\text { JKU } \\
\left(\mathrm{j} \sum \mathrm{Yj}^{2} / \mathrm{t}\right)-\mathrm{FK}\end{array}$ & $\begin{array}{l}\text { KTU } \\
\text { JKU /(r-1) }\end{array}$ & KTU/KTG \\
\hline Perlakuan & $\mathrm{t}-1=19$ & $\begin{array}{l}\text { JKP } \\
\left(\mathrm{j} \sum \mathrm{Yi}^{2} / \mathrm{r}\right)-\mathrm{FK}\end{array}$ & $\begin{array}{l}\text { KTP } \\
\text { JKP /(p-1) }\end{array}$ & KTP/KTG \\
\hline Amelioran(A) & $a-1=4$ & $\begin{array}{l}\text { JKA } \\
\left(\mathrm{j} \sum \mathrm{Yj}^{2} / \mathrm{r}\right)-\mathrm{FK}\end{array}$ & $\begin{array}{l}\text { KTA } \\
\text { JKA/(a-1) }\end{array}$ & KTA/KTG \\
\hline Dosis $\operatorname{Cr}(\mathrm{T})$ & $b-1=3$ & $\begin{array}{l}\mathrm{JKT}\left(\mathrm{j} \sum \mathrm{Yk}^{2} / \mathrm{r}\right)-\mathrm{FK} \\
\text { JKAT }\end{array}$ & $\begin{array}{l}\text { KTT } \\
\text { JKK/(t-1) }\end{array}$ & KTT/KTG \\
\hline $\begin{array}{l}\text { Interaksi } \\
\text { (AxB) } \\
\text { Galat }\end{array}$ & $\begin{array}{l}(a-1)(b-1)=12 \\
(r-1)(t-1)=19\end{array}$ & $\begin{array}{l}\text { JKP-JKA-JKT } \\
\text { JKG } \\
\text { JKT-JKP }\end{array}$ & $\begin{array}{l}\text { KTAT } \\
\text { JKAT/(a-1) (t-1) } \\
\text { KTG } \\
\text { JKG/ab(r-1) }\end{array}$ & KTAT/KTG \\
\hline Total & $(\mathrm{rt}-1)=39$ & JKT & 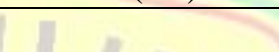 & \\
\hline
\end{tabular}

Berdasarkan rancangan penelitian maka disusun Analisis Sidik Ragam Rancangan Acak Kelompok Pola Faktorial seperti dapat dilihat pada Tabel 18. Pengujian perbedaan rata-rata pengaruh antar perlakuan menggunakan uji $\mathrm{F}$ pada taraf $5 \%$. Bila terdapat perbedaan yang nyata, pengujian dilanjutkan denganuji jarak berganda Duncan taraf 5\%.

\section{Pelaksanaan Penelitian}

Pengambilan Sampel Tanah untuk Analisis Tanah Awal

Sampel tanah diambil secara komposit pada lapisan olah tanah dengan kedalaman $0-30 \mathrm{~cm}$. Pengambilan sampel tanah dilakukan di salah satu kebun milik petani di desa Cibodas Lembang Jawa Barat. Sebelum dipindahkan ke polibeg, sampel tanah dihomogenkan terdahulu , lalu diambil $\pm 1 \mathrm{~kg}$ untuk analisis awal di laboratorium (Lampiran 2). Analisis $\mathrm{Cr}$ tanah dilakukan setelah satu minggu pemberian perlakuan dosis Cr. kemudian tanah diambil lagi secara komposit dan dihomogenkan lagi sesuai perlakuan dosis $\mathrm{Cr}$ yang sama (Lampiran 3). Selain tanah, analisis awal juga dilakukan untuk masing-masing amelioran (Lampiran 4).

\section{Persiapan Media Tanam}

Tanah yang telah dihomogenkan dipisahkan dari serasah-serasah dan sampah. Selanjutnya tanah disaring dengan saringan berdiameter 0,5 $\mathrm{cm}$ untuk memperoleh butiran tanah yang seragam. Kemudian tanah ditimbang sebanyak $5,73 \mathrm{~kg}$ polibeg ${ }^{-1}$ untuk media tanam (Lampiran
5), dan selanjutnya diurut sesuai dengan tata letak percobaan (Lampiran 6). Tanah di polibeg disiram setiap hari untuk menjaga kelembaban tanah (Lampiran 7).

\section{Pemberian Perlakuan}

Pemberian larutan $\mathrm{Cr}$ dilakukan tiga minggu sebelum pindah tanam, sedangkan amelioran diberikan dua minggu sebelum pindah tanam. Taraf dosis $\mathrm{Cr}$ dan amelioran diberikan pada masing-masing polibeg sesuai dengan perlakuan (Lampiran 8), dengan cara: (1) tanah di dalam polibeg dibongkar dan diletakkan pada media yang datar, (2) tanah dibagi menjadi empat bagian, (3) larutan logam berat disiram secara merata pada empat bagian tanah lalu diaduk rata, (4) setelah masing-masing bagian diaduk rata, tanah diaduk rata kembali secara keseluruhan sebelum dimasukkan ke polibeg. Tata cara pemberian amelioran sama dengan pemberian logam berat di atas. Pupuk dasar SP-18 dan $\mathrm{KCl}$ diberikan pada saat pindah tanam, sedangkan Urea diberikan sebanyak dua kali yaitu pada saat satu minggu dan dua minggu setelah pindah tanam (Lampiran 9).

\section{Persemaian Benih}

Benih tanaman selada disemai pada bumbun yang terbuat dari daun pisang dan pada media persemaian hingga umur tiga minggu sebelum dipindahkan ke dalam pot percobaan. Setiap bumbun terdiri atas tiga benih selada. Sedangkan pada media semai benih dimasukkan kedalam alur-alur secara merata, kemudian ditutup lagi 
dengan media semai. Media semai merupakan campuran tanah, bahan organik dan arang sekam dengan perbandingan 1:1:1.

\section{Penanaman}

Sebelum penanaman menggunakan polibeg, dilakukandahulu pemilihan bibit-bibit yang seragam dari hasil persemaian tanaman selada pada media semai, yang berupa bumbunbumbun yang terbuat dari daun pisang. Selanjutnya tanaman dipindahkan pada masingmasing polibeg. Setiap polibeg diisi dengan tiga bibit tanaman pada lubang tanam yang berbeda. Setelah satu minggu, disisakan satu tanaman tiap polibegnya, yaitu tanaman yang memiliki pertumbuhan yang paling baik.

\section{Pemeliharaan}

Beberapa pemeliharaan yang akan dilakukan adalah: (1) penyiraman tanaman yang dilakukan setiap pagi atau sore hari untuk menjaga kelembaban tanah, (2) penyiangan, dilakukan bila terdapat banyak gulma di sekitar tanaman utama, (3) penggemburan dan pembubunan, dilakukan bila tanah kelihatan padat atau akar tanaman mulai kelihatan di permukaan, (4) penanggulangan hama dilakukan secara mekanis.

\section{Panen}

Panen dilakukan setelah tanaman berumur 8 MST (Minggu Setelah Tanam). Selanjutnya dilakukan penimbangan berat segar tanaman. Cara panen yaitu dengan memotong pangkal batang tanaman yang berada di atas tanah atau mencabut seluruh bagian tanaman.

\section{Analisis pH Tanah dan Kadar Logam Berat}

Setelah dilakukan pemanenan, percobaan dilanjutkan dengan melakukan analisis jumlah $\mathrm{Cr}$ yang diserap oleh tanaman, serapan diukurpada bagian akar dan daun tanaman serta analisis kadar $\mathrm{Cr}$ total pada tanah yang digunakan sebagai media tanam percobaan (Lampiran 10). Selain itu dilakukan juga pengukuran $\mathrm{pH}$ tanah pada masing-masing perlakuan (Lampiran 11).

\section{HASIL DAN PEMBAHASAN \\ Pengamatan Penunjang \\ Panjang Akar}

Secara umum pengaruh pemberian amelioran dan dosis $\mathrm{Cr}$ terhadap panjang akar pada setiap perlakuan memperlihatkan perbedaan yang berfluktuatif jika dibandingkan dengan kontrol. Panjang akar tertinggi terdapat pada perlakuan $a_{1} t_{1}$ (kompos serasah daun jagung dengan dosis $\mathrm{Cr}$ sebesar $15 \mathrm{ppm}$ ) dan $\mathrm{a}_{4} \mathrm{t}_{2}$ (dolomit dengan dosis $\mathrm{Cr}$ sebesar $30 \mathrm{ppm}$ ) yaitu $23,5 \mathrm{~cm}$, sedangkan panjang akar yang terendah terdapat pada perlakuan $\mathrm{a}_{2} \mathrm{t}_{0}$ (arang sekam tanpa pemberian $\mathrm{Cr}$ ) yaitu $11,8 \mathrm{~cm}$.

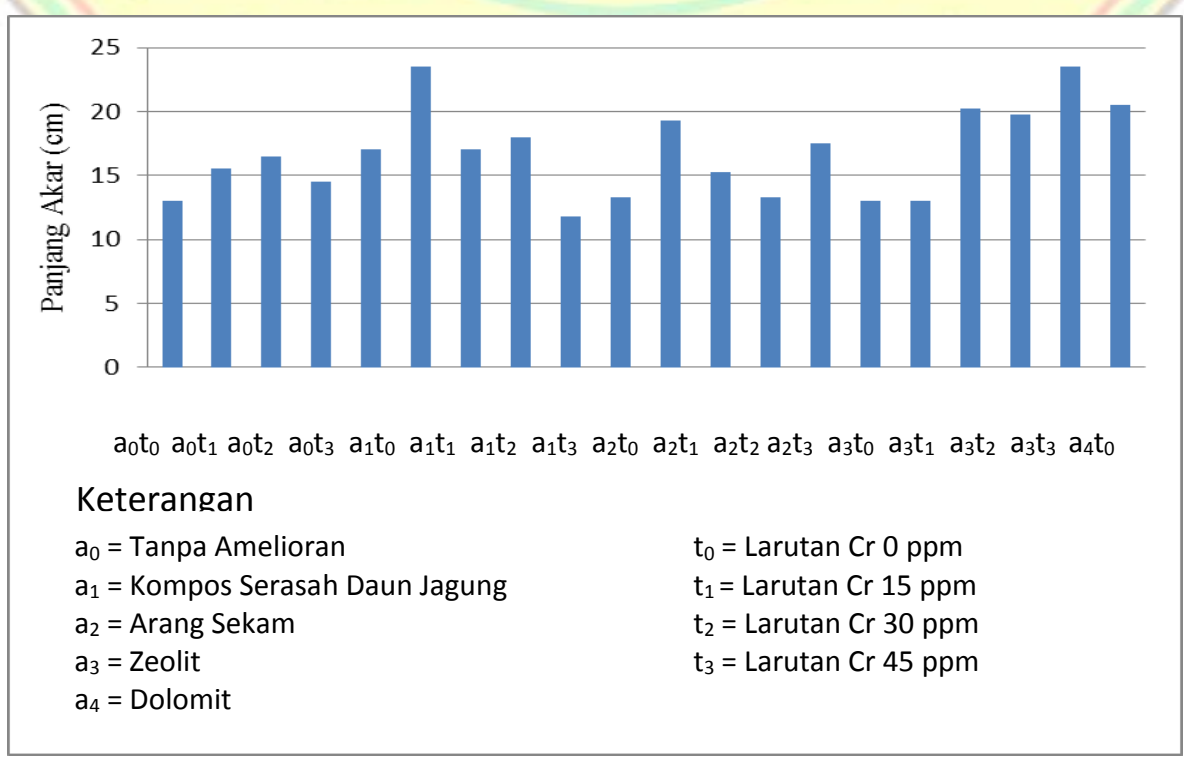

Gambar 1. Panjang Akar Selada pada Berbagai Kombinasi Perlakuan 
Gambar 1 memperlihatkanbahwa rata-rata panjang akar tertinggi yang hampirseragampadaberbagai dosis $\mathrm{Cr}$ terlihat pada perlakuan dolomit (a) $\mathrm{a}_{4}$. Hal ini disebabkan oleh tingginya kemampuan dolomit dalam meningkatkan $\mathrm{pH}$, menyebabkan berubahnya bentuk $\mathrm{Cr}^{6+}$ menjadi $\mathrm{Cr}^{3+}$ sehingga tingkat toksisitas $\mathrm{Cr}$ di dalam tanah berkurang. Secara langsung, terjadinya penurunan tingkat toksisitas logam berat akibat adanya penambahan amelioran akan mempengaruhi pertumbuhan akar tanaman. Hal ini sesuai dengan Fitter and Hay 1981, yang menyatakan bahwa stunting akar (kerdil akar), yang sering kali diikuti dengan warna kecoklatan pada akar dan kematian pada jaringan meristem pada tanaman dapat diakibatkan oleh toksisitas logamberat di dalam tanah.

Selain keracunan oleh logam berat, lambatnya pertumbuhan dan perkembangan akar pada tanaman juga disebabkan oleh tingginya suhu di rumah kaca sehingga terjadinya kehilangan unsur $\mathrm{N}$ akibat penguapan (Lampiran 12). Selain itu, terjadi juga pengikatan unsur $P$ oleh asam-asam organik di dalam tanah sehingga kecilnya ketersediaan unsur $\mathrm{P}$ bagi tanaman. Hardjowigeno, (2007) dan Suyono et al., (2008) menyatakan bahwa kurangnya ketersediaan unsur $\mathrm{N}$ dan $\mathrm{P}$ bagi tanaman dapat menghambat pertumbuhan dan perkembangan akar tanaman.

\section{Berat Kering Akar}

Hasil pengukuran memperlihatkan bahwa nialai rata-rata berat kering akar yang berbedabeda, akan tetapi rata-rata berat kering akar tanaman pada seluruh perlakuan menunjukkan nilai yang lebih tinggi dibandingkan dengan kontrol (Gambar 2). Pemberian amelioran berupa dolomit memperlihatkan rata-rata berat kering akar tertinggi dibandingkan pemberian amelioran lain.

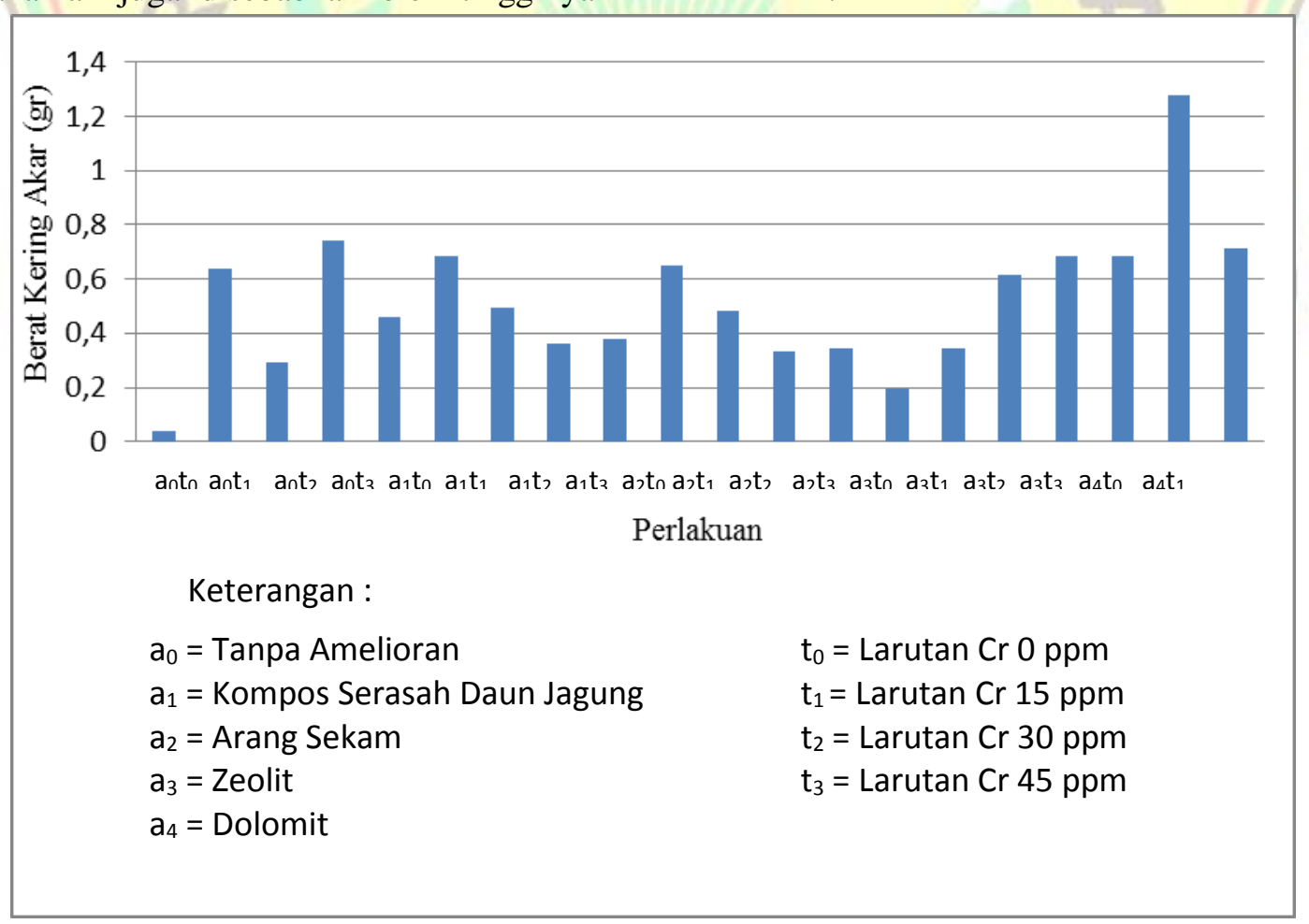

Gambar 2. Berat Kering Akar Selada pada Berbagai Kombinasi Perlakuan

Berdasarkan hasil pengamatan, diketahui bahwa rata-rata berat kering akar tanaman yang tertinggi yaitu pada perlakuan $\mathrm{a}_{4} \mathrm{t}_{2}$ (pemberian dolomit dengan dosis $\mathrm{Cr} 30 \mathrm{ppm}$ ) dengan berat $1,275 \mathrm{~g}$ dan yang terendah yaitu pada perlakuan $\mathrm{a}_{0} \mathrm{t}_{0}$ (kontrol) dengan berat rata-rata $0,04 \mathrm{~g}$
(Gambar 2). Kecilnya nilai berat kering akar pada perlakuan $a_{0} t_{0}$ disebabkan oleh adanya peningkatan tingkat toksisitas yang diberikan oleh logam berat yang terdapat di dalam tanah. Hal ini sesuai dengan Connell and Miller (1995) yang menyatakan bahwa semakin tinggi kadar 
logam berat yang terdapat di dalam tanah, maka pertumbuhan dan produktivitas tanaman akan mengalami penurunan, hingga dapat menyebabkan kematian bagi tanaman. Jika pertumbuhan dan produktivitas tanaman menurun, maka bobot tanaman juga mengalami penurunan, baik bobot hasil maupun bobot akar tanaman.

Tingginya bobot kering akar tanaman tergantung pada tingginya nilai bobot basah akar. Padaperlakuan $\mathrm{a}_{4} \quad$ (dolomit) memperlihatkan rata-rata nilai berat kering akar yang lebih tinggi dibandingkan dengan perlakuan amelioran yang lain, hal ini disebabkan oleh tingginya tingkat kebasaan yang dimiliki dolomit sehingga tingkat toksisitas oleh $\mathrm{Cr}^{6+}$ di dalam tanah dapat berkurang, pada kondisi tersebut menyebabkan pertumbuhan dan perkembangan akar tanamanakan meningkat, terutama dalam menyerap unsur hara di dalam tanah. Selain itu, tingginya laju pertumbuhan akar suatu tanaman juga dipengaruhi olehunsur $\mathrm{N}$ dan $\mathrm{P}$ yang tersedia bagi tanaman (Hardjowigeno, 2007).
Perlunya analisis bobot kering pada tanaman adalah untuk mengukur kemampuan tanaman sebagai penghasil fotosintat (Sudirja dan Wahyudin, 1998). Goldsworthy and Fisher (1991) menyatakan bahwa sebanyak 90 persen bahan kering suatu tanaman merupakan hasil dari fotosintesis. Rusaknya sistem perakaran tanaman pada tanah yang tercemar akan mengurangi kemampuan akar untuk menyerap air dan hara di dalam tanah, sehingga aktivitas fotosintesis akan menurun dan tanaman menjadi kerdil (Suyono, 2007).

\section{Jumlah Daun}

Jumlah daun masing-masing tanaman hingga minggu kedua relatif seragam hampir pada seluruh perlakuan. Perbedaan jumlah daun mulai terlihat pada minggu ke empat setelah tanam (Gambar 3). Pada kontrol, daun tanaman mengalami kematian pada minggu keempat dan keenam karena tingginya tingkat toksisitas yang diberikan logam berat pada minggu tersebut.

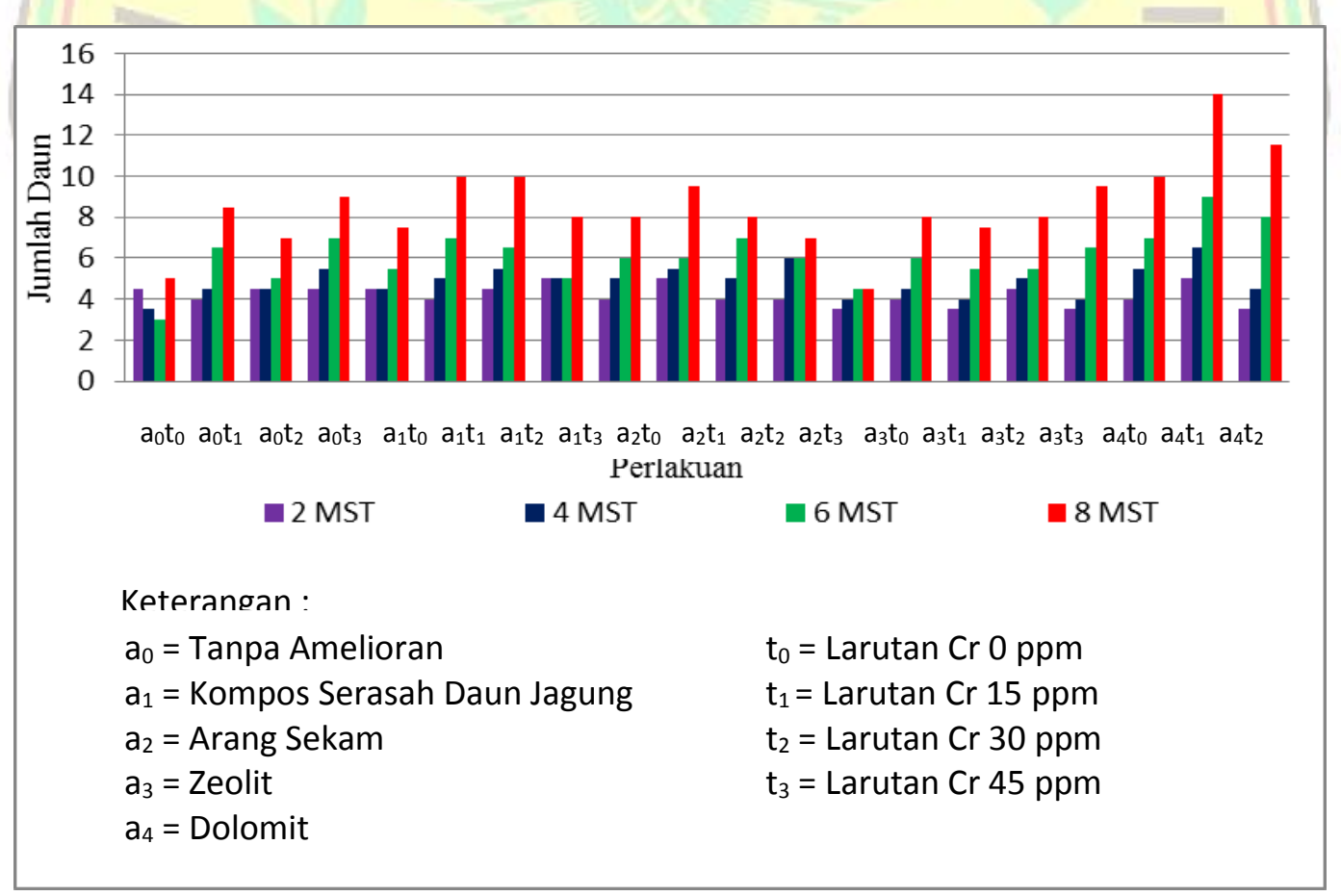

Gambar 3. Jumlah Daun Selada pada Berbagai Kombinasi Perlakuan.

Pada pengamatan terakhir, jumlah daun terbanyak terdapat pada perlakuan $a_{4} t_{2}$ (perlakuan dolomit dengan pemberian $\mathrm{Cr} 30$ ppm) yaitu sebanyak 14 helai daun (Gambar 3). Hal ini disebabkan tingginya kemampuan dolomit dalam menjaga kondisi dan bentuk 
ketersediaan $\mathrm{Cr}$ agar tetap stabil dan tidak meracuni tanaman. Dolomit merupakan salah satu bahan pembenah tanah yang berfungsi untuk meningkatkan $\mathrm{pH}$ tanah. Dolomitjika diberikanke dalam tanah akan terdisosiasi menjadi $\mathrm{Ca}^{2+}, \mathrm{Mg}^{2+}$ dan $\mathrm{CO}_{3}$. Menurut Kussow (1971), ion $\mathrm{CO}_{3}$ inilah yang berperandalammeningkatan $\mathrm{pH}$ tanah, karena ion tersebut mampu menarik $\mathrm{H}^{+}$darikomplek jerapan dan kemudian digantikan oleh kation dari bahan kapur. Meningkatnya $\mathrm{pH}$ tanah akan meningkatkan ketersediaan unsur hara di dalam tanah serta akan merubah bentuk $\mathrm{Cr}$ di dalam tanah menjadi stabil dan tidak meracuni tanaman.

Selain disebabkan oleh keracunan logam berat, perbedaan jumlah daun juga karena kurangnya ketersediaan $\mathrm{N}$ bagi tanaman. Menurut Hardjowigeno (2007) fungsi $\mathrm{N}$ adalah untuk memperbaiki pertumbuhan vegetatif tanaman, jika terjadi kekurangan pertumbuhan tanaman akan terhambat, ditandai dengan perubahan warna daun menjadi kuning dan kering, lalu mengalami keguguran. Begitu juga pengaruhnya dengan pupuk dasar yang diberikan, meskipun sesuai dengan dosis rekomendasi, diduga masih kurang bagi tanaman, karena terjadinya kehilangan akibat pencucian dan penguapan (Suyono et al., 2008).

\section{Pengamatan Utama pH Tanah}

Hasil analisis statistik menunjukkan tidak terjadi interaksi antara macam amelioran dan dosis $\mathrm{Cr}$ terhadap $\mathrm{pH}$ tanah. Tabel 2 menunjukkan pengaruh mandiri macam amelioran dan dosis Cr terhadap $\mathrm{pH}$ Tanah.

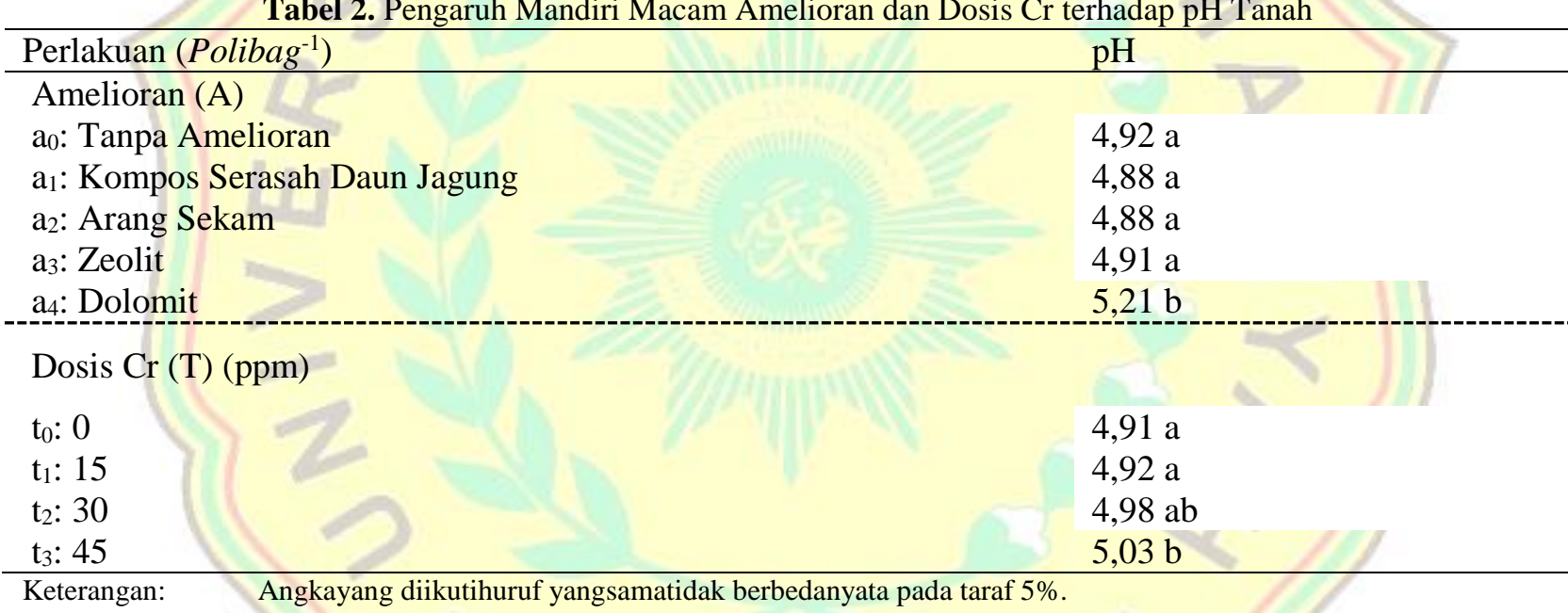

Pengaruh mandiri macam amelioran dengan berbagai dosis logam berat memberikan pengaruh yang berbeda nyata pada perlakuan $\mathrm{a}_{4}$ (dolomit). Dolomit berpengaruh nyata terhadap $\mathrm{pH}$ tanah dikarenakan tingginya kemampuan dolomit dalam mengikat asam-asam organik dan logam-logam toksik yang ada di dalam tanah serta tingginya distribusi ion $\mathrm{H}^{+}$yang diberikan oleh dolomit (Suyono et al., 2008). Tingginya kemampuan suatu amelioran dalam mendistribusikan ionH $\mathrm{H}^{+}$di dalam tanah, maka tingkat kemasaman tanah juga akan semakin menigkat (Hardjowigeno, 2007).

Kapur dolomit dengan rumus kimia $\mathrm{CaMg}\left(\mathrm{CO}_{3}\right)_{2}$, memiliki kemampuan yang tinggi dalam meningkatkan $\mathrm{pH}$ tanah. Hal ini karena kandungan $\mathrm{CO}_{3}$ pada dolomit yang memiliki kemampuan menarik $\mathrm{H}^{+}$dari komplek jerapan dan kemudian digantikan oleh kation dari bahan kapur (Kussow, 1971), sehingga $\mathrm{H}^{+}$berubah menjadi $\mathrm{OH}^{-}$. Suyono et al., 2008 juga menjelaskan bahwa selain memiliki kemampuan dalam meningkatkan $\mathrm{pH}$, dolomit juga mampu menyediakan unsur hara seperti $\mathrm{Ca}$ dan $\mathrm{Mg}$ bagi tanaman, hal ini sesuai dengan reaksi sebagai berikut:

$$
\mathrm{CaMg}\left(\mathrm{CO}_{3}\right)_{2} \rightarrow \mathrm{Ca}^{++}+\mathrm{Mg}^{++}+2 \mathrm{H} \mathrm{CO}_{3}
$$

Meningkatnya $\mathrm{pH}$ tanah ke arah netral menyebabkan bentuk $\mathrm{Cr}^{6+}$ yang bersifat labil dan toksik berubah menjadi $\mathrm{Cr}^{3+}$ yang bersifat stabil 
dan tidak tersedia bagi tanaman (Cahyati, 2000). Jika total $\mathrm{Cr}^{3+}$ dapat dikurangi maka tingkat toksisitas $\mathrm{Cr}$ terhadap tanaman juga akan berkurang, selain itu ketersediaan unsur hara juga akan meningkat bagi tanaman (Hardjowigeno, 2007).

\section{Cr Total Tanah}

Hasil analisis statistik menunjukkan bahwa terdapat interaksi antara pemberian amelioran dengan taraf dosis $\mathrm{Cr}$ terhadap $\mathrm{Cr}$ total tanah (Tabel 4). Terlihat bahwa Cr total tanah terkecil terdapat pada pemberian kompos serasah daun jagung tanpa pemberian logam $\mathrm{Cr}\left(\mathrm{a}_{1} \mathrm{t}_{0}\right)$ yaitu 45,5 ppm. Sedangkan $\mathrm{Cr}$ total tanah tertinggi terdapat pada pemberian zeolit dengan taraf dosis $\mathrm{Cr} 45 \mathrm{ppm}\left(\mathrm{a}_{3} \mathrm{t}_{3}\right)$ yaitu $165,5 \mathrm{ppm}$.

Tabel 3. Interaksi antara Macam Amelioran dan Dosis Cr terhadap Cr Total Tanah (ppm)

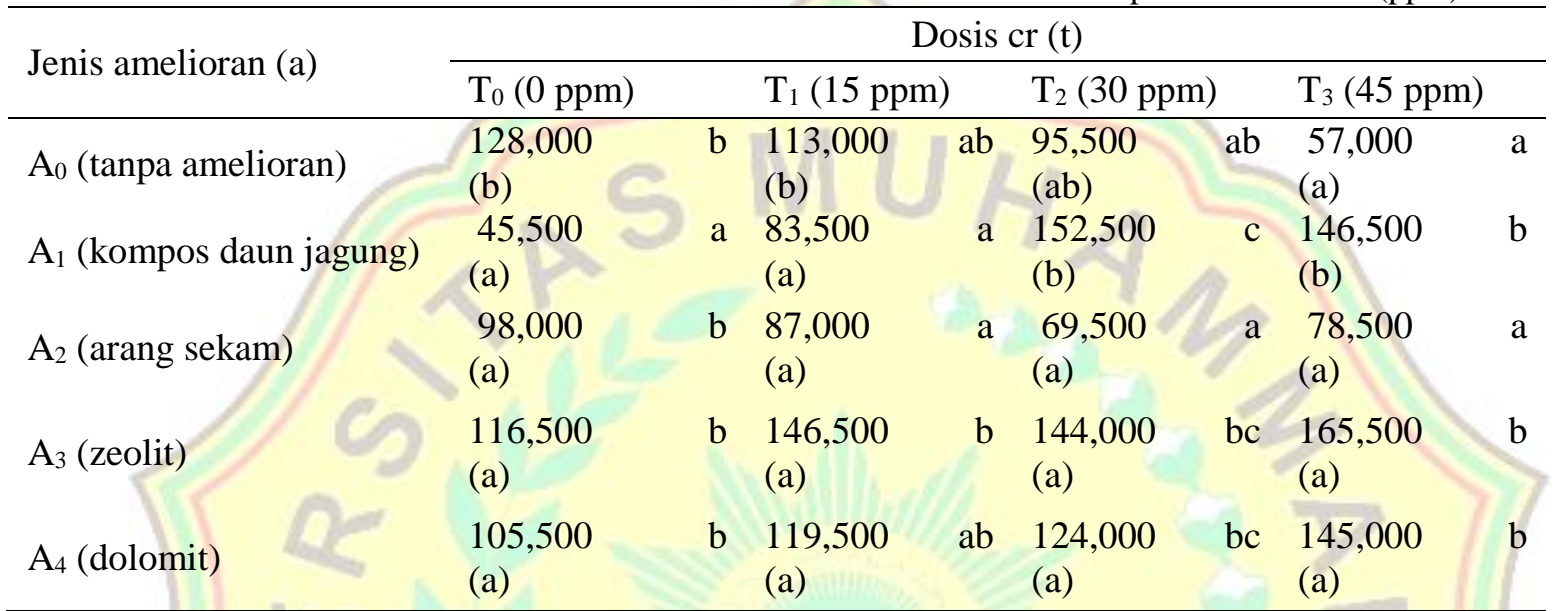

Keterangan: huruf dalam kurung dibaca arah horizontal, huruf kecil tanpa kurung dibaca arah vertikal. Angka yang diikuti huruf yang tidak sama berbeda nyata pada taraf $5 \%$

Pada Tabel 3 dapat dilihat bahwa amelioran yang memberikan pengaruh terbaik pada pemberian berbagai dosis $\mathrm{Cr}$, terdapat pada pemberian arang sekam dengan dosis $\mathrm{Cr} 30$ ppm. Hal ini dikarenakan arang sekam bersifat absorben sehingga memiliki daya jerap yang tinggi terhadap kation-kation logam berat di dalam tanah, selain itu arang sekam yang bersifat organik juga memiliki gugus-gugus fungsi yang dapat berikatan dengan logamlogam yang terdapat di dalam tanah. Tan (1995) menyatakan bahwa pembentukan kompleks organik-logam merupakan suatu reaksi antara ion logam dan ligan yang terdapat pada gugusgugus fungsi bahan organik, ligan tersebut dapat berupa suatumolekul netral $\left(\mathrm{NH}_{3}\right)$ atau anion seperti:

$$
\mathrm{R}-\mathrm{CH}_{2}-\mathrm{COO}^{-}
$$

Pada pemberian amelioran berupa kompos daun jagung, zeolit dan dolomit, Cr total tanah cendrung meningkat seiring ditingkatkannya pemberian dosis $\mathrm{Cr}$. Hal ini karena kurangnya kemampuan kompos daun jagung, zeolit dan dolomit untuk menjerap dan mengikat $\mathrm{Cr}$ di dalam tanah. Walaupun dolomit tidak mampu mengurangi Crtotal tanah, akan tetapi dolomit yang memiliki kemampuan tinggi untuk meningkatkan $\mathrm{pH}$ tanah, maka secara langsung akan mempengaruhi bentuk dan kondisi $\mathrm{Cr}$ di dalam tanah. Bentuk dan kondisi $\mathrm{Cr}$ di dalam tanah akan mempengaruhi tingkat toksisitas dan ketersediaannya bagi tanaman.

Meningkatnya $\mathrm{pH}$ ke arah netral atau alkalin akan menyebabkan $\mathrm{Cr}$ bervalensi $\mathrm{III}\left(\mathrm{Cr}^{3+}\right)$ akan semakin mudah diendapkan atau diabsorpsi oleh senyawa-senyawa organik (Slamet et al., 2005). Tingginya mineral liat alofan dan kandungan bahan organik yang dimiliki Andisols serta terjadinya perubahan sifat kimia pada Andisols jika mengalami kering udara, akan menyebabkan tingginya akumulasi $\mathrm{Cr}$ yang bervalensi III $\left(\mathrm{Cr}^{3+}\right)$ di dalam tanah. Hal ini yang diduga menjadi salah satu penyebab terjadinya peningkatan $\mathrm{Cr}$ di dalam tanah pada penelitian ini. 


\section{Serapan $\mathrm{Cr}$}

Hasil analisis statistik menunjukkan bahwa terdapat interaksi antara pemberian macam amelioran dengan dosis $\mathrm{Cr}$ terhadap jumlah serapan $\mathrm{Cr}$ oleh tanaman selada (Tabel 4).

Tabel 4. Interaksi antara Macam Amelioran dan Dosis Cr terhadap Serapan $\mathrm{Cr}$ (ppb)

\begin{tabular}{|c|c|c|c|c|c|c|c|c|}
\hline \multirow{2}{*}{ Jenis Amelioran (A) } & \multicolumn{8}{|c|}{ Dosis Cr (T) } \\
\hline & $\mathrm{t}_{0}(0 \mathrm{ppb})$ & & $\mathrm{t}_{1}(15 \mathrm{ppb})$ & & $\mathrm{t}_{2}(30 \mathrm{ppb})$ & & $\mathrm{t}_{3}(45 \mathrm{ppb})$ & \\
\hline $\mathrm{a}_{0}$ (Tanpa Amelioran) & $\begin{array}{l}0,014 \\
\text { (a) }\end{array}$ & $\mathrm{bc}$ & $\begin{array}{l}0,014 \\
\text { (a) }\end{array}$ & $\mathrm{b}$ & $\begin{array}{l}0,014 \\
\text { (a) }\end{array}$ & $\mathrm{b}$ & $\begin{array}{l}0,014 \\
\text { (a) }\end{array}$ & $\mathrm{b}$ \\
\hline $\mathrm{a}_{1}$ (Kompos daun jagung) & $\begin{array}{l}0,017 \\
\text { (a) }\end{array}$ & $\mathrm{cd}$ & $\begin{array}{l}0,019 \\
\text { (a) }\end{array}$ & $\mathrm{c}$ & $\begin{array}{l}0,020 \\
\text { (a) }\end{array}$ & $\mathrm{c}$ & $\begin{array}{l}0,020 \\
\text { (a) }\end{array}$ & $\mathrm{c}$ \\
\hline $\mathrm{a}_{2}$ (Arang Sekam) & $\begin{array}{l}0,018 \\
\text { (b) }\end{array}$ & & 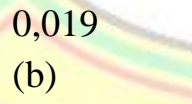 & & $\begin{array}{l}0,017 \\
\text { (b) }\end{array}$ & bc & $\begin{array}{l}0,011 \\
\text { (a) }\end{array}$ & $\mathrm{b}$ \\
\hline $\mathrm{a}_{3}$ (Zeolit) & $\begin{array}{l}0,010 \\
\text { (a) }\end{array}$ & & $\begin{array}{l}0,009 \\
\text { (a) }\end{array}$ & & $\begin{array}{l}0,009 \\
\text { (a) }\end{array}$ & a & $\begin{array}{l}0,011 \\
\text { (a) }\end{array}$ & $\mathrm{b}$ \\
\hline $\mathrm{a}_{4}$ (Dolomit) & $\begin{array}{l}0,009 \\
\text { (a) }\end{array}$ & $\mathrm{a}$ & $\begin{array}{l}0,006 \\
\text { (a) }\end{array}$ & & $\begin{array}{l}0,006 \\
\text { (a) }\end{array}$ & a & $\begin{array}{l}0,007 \\
\text { (a) }\end{array}$ & \\
\hline
\end{tabular}

Keterangan: Huruf dalam kurung dibaca arah horizontal, huruf kecil tanpa kurung dibaca arah vertikal. Angka yang diikuti huruf yang tidak sama berbeda nyata pada taraf $5 \%$.

Dari Tabel 4 terlihat bahwa pada kontrol $\left(\mathrm{a}_{0}\right)$ terdapat kesamaan jumlah serapan $\mathrm{Cr}$ oleh tanaman untuk setiap pemberian dosis $\mathrm{Cr}$, sedangkan rata-rata serapan $\mathrm{Cr}$ terbesar yaitu pada perlakuan kompos serasah daun jagung dengan pemberian dosis $\mathrm{Cr}$ sebesar $30 \mathrm{ppm}$ $\left(\mathrm{a}_{1} \mathrm{t}_{2}\right)$ dan $45 \mathrm{ppm}\left(\mathrm{a}_{1} \mathrm{t}_{3}\right)$ yaitu $0,020 \mathrm{ppb}$. Hal ini disebabkan oleh rendahnya kemampuan kompos untuk meningkatkan $\mathrm{pH}$ tanah sehingga rendah pula $\mathrm{Cr}^{3+}$ yang terbentuk.

Pada pemberian dolomit, jumlah serapan $\mathrm{Cr}$ memberikan hasil yang terkecil, walaupun pada $\mathrm{Cr}$ total memberikan hasil yang tinggi. Hal ini menunjukkan bahwa dolomit memiliki kemampuan yangrendah untuk menjerap $\mathrm{Cr}$ di dalam tanah, akan tetapi memiliki kemampuan yang tinggi dalam meningkatkan $\mathrm{pH}$ tanah. Dadang (2006) menjelaskan bahwa $\mathrm{pH}$ tanah akan mempengaruhi ketersediaan kation-kation logam berat di dalam tanah, semakin tinggi $\mathrm{pH}$ tanah maka kation-kation logam berat akan semakin rendah dan menjadi tidak tersedia bagi tanaman.

Meningkatnya $\mathrm{pH}$ ke arah netral, $\mathrm{Cr}^{3+}$ yang bersifat tidak larut dan immobil lebih banyak terbentuk di dalam tanah, sehingga $\mathrm{Cr}$ akan lebih banyak terakumulasi di dalam tanah dibandingkan dengan yang terserap oleh tanaman (Subowo et al., 1994). Selain itu, Bruce (2002) juga menjelaskan bahwa $\mathrm{Cr}^{3+}$ memiliki afinitas kuat terhadap ion bermuatan negatif dan koloid pada tanah yang mengandung oksigen seperti ion hidroksil dan membentuk senyawa yang hampir tidak larut sehingga bersifat stabil dan tidak berbahaya bagi tanaman, sedangkanCr ${ }^{6+}$ bersifat lebih larut dan tidak stabil sehingga dapat berbahaya bagi tanaman.

Jika membandingkan jumlah $\mathrm{Cr}$ yang diserap oleh tanaman (Lampiran 13), dengan jumlah toleransi $\mathrm{Cr}$ yang untuk dikosumsi perharinya, jumlah $\mathrm{Cr}$ yang diserap oleh selada pada penelitian ini masih berada jauh di bawah ambang batas toleransi, dengan kata lain hasil tanaman masih layak untukdikonsumsi karena kandungan $\mathrm{Cr}$ tanaman masih di bawah 0,07 ppm (Nanik, 2008), hal ini disebabkan oleh kecilnya $\mathrm{Cr}^{6+}$ yang bersifat lebih larut dan tersedia bagi tanaman, sehingga kecil jumlah $\mathrm{Cr}$ yang terserap oleh tanaman selada.

\section{Hasil Selada}

Hasil analisis statistik menunjukkan tidak terjadi interaksi antara macam amelioran dengan dosis $\mathrm{Cr}$ terhadap hasil selada. Tabel 5 menunjukkan pangaruh mandiri macam amelioran dan dosis $\mathrm{Cr}$ terhadap hasil selada (Tabel 5). 
Tabel 5. Pengaruh Mandiri Macam Amelioran dan Dosis Cr Terhadap Hasil Tanaman Selada (Lactuca sativa, L)

\begin{tabular}{ll}
\hline Perlakuan $\left(\right.$ Polibeg $\left.^{-1}\right)$ & Hasil $\left(\mathrm{gr} \mathrm{Polibeg}^{-1}\right)$ \\
\hline Amelioran $(\mathrm{A})$ & \\
$\mathrm{a}_{0}$ : Tanpa Amelioran & $8,0 \mathrm{a}$ \\
$\mathrm{a}_{1}$ : Kompos Serasah Daun Jagung & $14,3 \mathrm{a}$ \\
$\mathrm{a}_{2}$ : Arang Sekam & $13,7 \mathrm{a}$ \\
$\mathrm{a}_{3}$ : Zeolit & $7,9 \mathrm{a}$ \\
$\mathrm{a}_{4}$ : Dolomit & $41,6 \mathrm{~b}$
\end{tabular}

Dosis Cr (T) (ppm)

$\mathrm{t}_{0}: 0$

$\mathrm{t}_{1}: 15$

$\mathrm{t}_{2}: 30$

9,3 a

$15,1 \mathrm{a}$

$\mathrm{t}_{3}: 45$

26,2 a

17,8 a

Keterangan: $\quad$ Angka-angka yang diikutihurufyang sama tidak berbedanyata pada taraf 5\%.

Tingginya kemampuan dolomit dalam meningkatkan $\mathrm{pH}$ menyebabkan tingginya reaksi reduksi $\mathrm{Cr}$ sehingga menurunkan potensi pengaruh $\mathrm{Cr}^{6+}$ terhadap tanaman. Hal ini terlihat pada jumlah serapan $\mathrm{Cr}$ yang terkecil terjadi pada pemberian dolomit, sehingga tanaman memiliki daya tumbuh yang tinggi. Selain memiliki kemampuan dalam meningkatkan $\mathrm{pH}$, kemampuan dolomit dalam meningkatkan kapasitas tukar kation, menambah unsur $\mathrm{P}, \mathrm{Ca}$ dan $\mathrm{Mg}$ serta mengurangi tingkat toksisitas yang ditimbulkan oleh logam berat terhadap tanaman, menyebabkan tanaman tetap memiliki daya tumbuh yang baik dan mampu menyerap unsur hara secara optimal pada tanah yang tercemar logam berat (Suyono et al, 2008).

Logam berat yang terdapat di dalam tanah berada dalam bentuk bebas dan tidak bebas (Charlena, 2004). Hal ini akan berpengaruh terhadap tanaman yang tumbuh pada tanah yang tercemar logam berat. Dalam keadaan bebas, $\mathrm{Cr}$ dapat bersifat racun dan tersedia bagi tanaman sehingga akan terserap oleh akar tanaman, dan selanjutnya akan terangkut melalui jaringanjaringan tanaman hingga bagian batang dan daun pada tanaman sehingga akan mempengaruhi pertumbuhan dan hasil tanaman (Bluskov et al, 2002).

Difusi dan aliran massa adalah mekanisme terserapnya $\mathrm{Cr}$ oleh akar tanaman, $\mathrm{Cr}$ yang diserap oleh akar akan mengalami pengikatan, inaktifasi dan pengendapan (Bluskov et al,
2002). Setelah terserapnya $\mathrm{Cr}^{6+}$ oleh tanaman, $\mathrm{Cr}$ selanjutnya akan terakumulasi di dalam tanaman, hal ini disebabkan adanya perubahan bentuk $\mathrm{Cr}$ di dalam jaringan tanaman. Pada akar, kebanyakan $\mathrm{Cr}^{6+}$ diubah menjadi $\mathrm{Cr}^{3+}$-asetat yang cenderung terakumulasi pada epidermis dan korteks, sedangkan pada daun, $\mathrm{Cr}$ mengalami translokasi $\mathrm{Cr}^{3+}$-oksalat dan disimpan di dalam epidermis (Bluskov et al, 2002).

\section{KESIMPULAN DAN SARAN}

\section{Kesimpulan}

1) Terjadi interaksi antara macam amelioran dengan dosis logam $\mathrm{Cr}$ terhadap $\mathrm{Cr}$ total tanah dan serapan $\mathrm{Cr}$, tetapi tidak terjadi interaksi terhadap $\mathrm{pH}$ tanah dan hasil tanaman selada.

2) Terdapat pengaruh mandiri Pemberian macam amelioran dan dosis $\mathrm{Cr}$ terhadap $\mathrm{pH}$ tanah dan hasil tanaman selada. Dolomit merupakan amelioran terbaik dalam meningkatkan $\mathrm{pH}$ tanah sebesar 5,21 dan memberikan hasil terbaik pada tanaman selada sebesar 41,6 gr polibeg ${ }^{1}$.

3) Kombinasi arang sekam dengan $\mathrm{Cr}$ dosis 30 ppm merupakan kombinasi terbaik dalam mengurangi $\mathrm{Cr}$ total tanah, sedangkan kombinasi dolomit dengan $\mathrm{Cr}$ dosis 15 dan 30 ppm yang terbaik dalam mengurangi serapan Cr. 
4) Dolomit merupakan amelioran terbaik dalam meningkatkan $\mathrm{pH}$ tanah, menurunkan serapan $\mathrm{Cr}$ serta memberikan rata-rata hasil tanaman selada terbaik, sedangkan arang sekam mampu menurunkan rata-rata $\mathrm{Cr}$ total tanah.

\section{Saran}

Saran yang dapat diberikan dari penelitian ini adalah Melakukan penelitian lanjutan dengan menggunakan jenis amelioran lain seperti terak baja, arang aktif, dan amelioran lainnya yang diduga lebih efektif. Selain itu, dikarenakan sifat Andisols yang irreversible, maka kelembaban tanahnya harus tetap terjaga agar tidak merubah sifat kimia pada Andisols.

\section{DAFTAR PUSTAKA}

M. Nurhuda Dr.Rer.nat. " tungku biomasa UB mendukung terwujudnya target penurunan emisi $26 \%$ dan kemandirian energi “ Universitas Brawijaya Malang 2009.

Alloway, B.J. 1990. Soil Processes and Behaviour of Metal. P. In Heavy metals in Soils. 2nd ed. Blackie Glasgow and London Halstead press. John Wiley and Sons Inc, New York.

Aomine, S and Jackson, M.L. 1959. Allophane Determination in Andisol by Cation Exchange Capacity Delta Value. Soil. Sci. Soc.Amer.Proc.

Barbarick, K.A and Pirela, H.J. 1983. Agronomic and Horticultural Uses of Zeolites: A Rivew in Zeo Agricultural Westview Press, Boulder Colorado.

Bluskov, J. M. Arocena, J. P. Young, and O.O. Omotoso. 2002. Behavior of Chromium in the Rhizosphere of Brassica juncea (Indian Mustard). University of Northern BC, Prince George, BC, Canada V2N 4Z9 Natural Resources Canada, CANMET Energy Technology Centre, Devon, AB, Canada

Bruce, R. 2002. Chemical Transformations of Chromium in Soils: Relevance to Mobility, Bio-availability and Remediation. The Cromium File. International Cromium
Development Association, College Park USA.

Cahyati. 2000. Pengaruh Kompos Jerami Padi dan Zeolit terhadap $\mathrm{pH}, \mathrm{Cr}$-terlarut dan $\mathrm{Cr}$ total Tanah Sawah Terpapar Limbah Industri serta Serapan $\mathrm{Cr}$ pada Akar Tanaman Padi Sawah (Oryza Sativa). Skripsi Jurusan Ilmu Tanah dan Sumberdaya Lahan Fakultas Pertanian Universitas Padjadjaran, Jatinangor (Tidak Dipublikasikan)

.2004. Pencemaran Logam Berat Timbal ( $\mathrm{Pb}$ ) dan Cadmium ( Cd ) pada Tanaman Sayursayuran. Institut Pertanian Bogor, Bogor. Online: http://www.rudyct.com/PPS702ipb/09145/charlena.pdf. (Diakses pada 27 Januari 2010).

Connell, D.W andMiller G.J.1995. Kimiadan Ekotoksikologi Pencemaran. DiterjemahkanolehYantiKoestoer.UI Press, Jakarta.

Craig. 1980. The Natural Environmental and Biogheochemical Cycles. Spinger Verlag, Berlin and New York.

Dadang. 2006. Aplikasi Dolomit, Bahan Organik, dan Pupuk NPK pada Tanah Di Cemari Cd: Keterkaitan Antara Sifat Kimia Tanah dan Ketersediaan $\mathrm{Cd}$ dan Bobot Kering Tomat. Ilmu Tanah. Institut Pertanian Bogor, Bogor Online: http://repository.ipb.ac.id/handle/12345678 9/1138. (Diakses pada 06 April 2010).

Darmono. 1995. Logam dalam Sistem Makhluk Hidup. Universitas Indonesia Press, Jakarta

Diantariani. N. P, Sudiarta. I. W dan Elentiani. N. K. 2008. Proses Biosorpsi dan Desorpsi Ion $\mathrm{Cr}$ (VI) pada Biosorben Rumput Laut Eucheuma Spinosum. Jurusan Kimia FMIPA Universitas Udayana. Bukit Jimbaran.

Online:http://ejournal.unud.ac.id/abstrak/jkim-vol2-no1-diantariani.pdf. (Diakses pada 10 April 2010).

Dudal, R. dan M. Soepraptohardjo. 1960. Some Consideration on The Genetic Relationship between Latosols and Andisols in Java (Indonesia). Trans. Seventh Intern. Congr. Soil Sci, Madison. 
Gomez, Kwanci A. 1995. Prosedur Statistik PenelitianPertanian. Universitas Indonesia Pres, Jakarta.

Goldsmanthy, P.R dan Fisher. N.M. 1991. Fisiologi Tanaman Budidaya Tropik. Terjemahan Tohari. Gajah Mada University Press, Yogyakarta.

Gurhayanto,AndiBukit,HolinOnggo.1995.Pemanf aatan Kapur Dolomit untukPembuatan MgOSebagai Bahan Baku Kordierit. Seminar Ilmiah Hasil Penelitian dan Pengembangan Bidang Fisika Terapan. Online:

http://elib.pdii.lipi.go.id/katalog/index.php/ searchkatalog/./2004.pdf. (Diakses pada 07 April 2011).

Haghiri, F. 1973. Studies on Cadmium Toxicity In Plants. Environmental Pollution. Online: www.plantstress.com/articles/toxicity i/cad mium.pdf. (Diakses Pada 10 April 2010).

Hardjowigeno, S. 2007. Ilmu Tanah. Akademika Pressindo, Jakarta

2003. Klasifikasi Tanah dan Pedogenesis. Akademika Presindo,Jakarta. Edisi Revisi.

Hartatik. W dan Idris. K 2008. Kelarutan Fosfat Alam dan SP-36 dalam Gambut yang Diberi Amelioran. Fakultas Pertanian Institut Pertanian Bogor, Bogor. Online: http://bbsdlp.litbang.deptan.go.id/....../down load/jti27juli2009.pdf. (Diakses pada 09 April 2010).

Itanna F. 2002. Metals in Leafy Vegetables Grown in Addis Ababa and Toxicological Implications. Ethiopia Journal Health Development. Vol. 16 (3): p. 295-302.

Jones, L.H.P.H. and S.C. Jarvis. 1981. The Fate of Heavy Metal In Greenland, D.J. and M.H.B. Hayes (ed); The Chemistry of Soil Processes. John Wiley and Sons Ltd, New York.

Kostov. 1968. Mineralogy. Oliver and Buyd, Edenburg and London. Online: www.balogh.com/schweizerbart/geology_ monographs.html. (Diakses pada 09 April 2010).

Kussow, W.R. 1971. Introduction to Soil Chemictry Fertility Project. Departemen
Ilmu-ilmu Tanah, Faperta. Institut Pertanian Bogor, Bogor.

Mawardi. E. 2009. Pengaruh Takaran Amelioran Terhadap Serapan $\mathrm{Ca}$ dan $\mathrm{Mg}$ serta Pertumbuhan Padi Di Lahan Gambut Tropohemist. Solok, Sumatra Barat. Online:http://sumbar.litbang.deptan.go.id/in d/index.php/hasil-litkaji-mainmenu-46/40tanaman-pangan/138. (Diakses pada 02 April 2010).

Mc Grath and Smith. 1990. Heavy Metal: Chromium and Nickel. Online:www.linkinghub.elsevier.com.

(Diakses Pada 22 April 2010).

Mentri Pertanian. 2006. Deskripsi Tanaman Selada. Online:www.deptan.go.id. (Diakses Pada 22 April 2010).

Nanik. $\mathrm{H}$.

S.

2008.KandunganChromiumpadaPertanian,

Sedimen dan KerangDarah(Andara granosa)DiWilayahPantai Sekitar Muara SungaiSayungDesaMorosariKabupatenDe mak. Jawa Tengah. Laboratorium Ekologi dan Biosistematik. Universitas Diponegoro. BIOMA. Vol. 10, No. 2, Hal. 53-56. Online:

eprints.undip.ac.id/view/year/2008.html.

(Diakses pada 10 April 2010).

Nugroho, Budi. 2001. Ekologi Mikroba pada Tanah Terkontaminasi Logam Berat. Makalah Falsafah Sains. Program Pascasarjana, Institut Pertanian Bogor, Bogor.

Nurfindarti. E 2004. Deteksi Logam Berat pada Sayuran Berbentuk Umbi. Perpustakaan Departemen Teknik Lingkungan. Institut Teknologi Bandung. Bandung.

Nurjaya, Emona Zihan dan M. Sri Saeni. 2006. Pengaruh Amelioran terhadap $\mathrm{Pb}$ Tanah, Serapan $\mathrm{Pb}$ serta Hasil Tanaman Bawang Merah pada Inceptisols. Jurnal Ilmu-ilmu Pertanian Indonesia. Vol 8, No 2.

Palar, H. 1994. Pencemaran dan Toksikologi Logam Berat. PT. Rineka Cipta, Jakarta.

Parfitt R.L. D.J. Giltrap dan J.S. Whitton. 1995, Contribution of Organic Matter and Clay Minerals to the Cation Exchange Capacity 
of Soil, Commun, Soil Sci.- Plant Annual 26:1343:1355.

Salam, A.K., Sarno dan S. Djuniwati. 1998.

Perubahan Kelarutan Tembaga dan Kadmium dalam Kolom Tanah dengan Perlakuan Kapur dan Kompos Daun Singkong Akibat Pencucian dengan Air. Jurnal Tanah Tropika.

Santoso. 1985. Sifat dan Ciri Andosols. Jurusan Tanah, Fakultas Pertanian Universitas Brawijaya, Malang.

Sartji. T. 2004. Peranan Mikroorganisme dalam Mengurangi Efek Toksik Pada Tanah Terkontaminasi Logam Berat. Institut Pertanian Bogor, Bogor.

Soil Survey Staff. 1975.Soil Taxonomy.A Basic SystemofSoilClasification

forMakingandInterprantingSoilSurvey.Soil CnservationService, V.S. Dept. Agric. Handb. 436.U.S. Gant,Printing Office, Washington D.C.

Slamet, Arbianti dan Daryanto. 2005. Pengolahan Limbah Organik (Fenol) dan Logam Berat $\left(\mathrm{Cr}^{6+}\right.$ atau $\left.\mathrm{Pt}^{4+}\right)$ Secara Simultan dengan Fotokatalis $\mathrm{TiO} 2, \mathrm{ZnO}-$ $\mathrm{TiO}_{2}$, dan $\mathrm{CdS}-\mathrm{TiO}_{2}$. Makalah Teknologi. Vol. 9, No. 2. Departemen Teknik Gas dan Petrokimia. Fakultas Teknik Universitas Indonesia, Jakarta Online: Repository.ui.ac.id/dokumen/lihat/494.pdf. (Diakses pada 12 November 2010).

Stokes, P.,T. Davey. 1981. A New Look of Heavy Metal. Water Pollution Control Journal.

Subowo, A. Mukti, Prastowo Kabar, dan J. Sri Adiningsih. 1994. Pengaruh Penambahan Krom pada Tanah Alivuvial Gleik, Latosol Haplik dan Grumusol Eutrik terhadap Pertumbuhan Tanaman Cabe Merah. Makalah Penelitian Tanah. Pusat Penelitian Tanah dan Agroklimat, Bogor.

Sudirja, R dan A. Wahyudin 1998. Pengaruh Air Buangan Tekstil terhadap Pertumbuhan dan Hasil Padi Sawah (Oryza sativa L.) Varietas IR-64. Studi Kasus Di Daerah Pengairan Sungai Cikijing Kecamatan Rancaekek Kabupaten Bandung. Jurusan Ilmu Tanah dan Sumberdaya Lahan
Fakultas Pertanian Universitas Padjadjaran, Jatinangor. (Tidak Dipublikasikan).

Sudirja, R. 1999. Penanganan Tanah Tercemar Limbah Industri Tekstil Melalui Bahan Organik dan Belerang. Jurusan Ilmu Tanah Fakultas Pertanian Universitas Padjadjaran, Jatinangor. (Tidak Dipublikasikan).

Suganal. 1989. Penggunaan Zeolit Alam Bayah Untuk Pengolahan Air Limbah Industri Elektro Planting Di DKI Jakarta. Dirjen Pertambangan Umum. Pusat Pengembangan Teknologi Mineral, Bandung.

Sulaeman, S. dan Evianti. 2005. Petunjuk Teknis Analisis Kimia Tanah, Tanaman, Air dan Pupuk. Balai Penelitian Tanah Badan Penelitian dan Pengembangan Pertanian. Departemen Pertanian, Bogor

Suyono. A.D, Tien Kurniatin, Siti Mariam, Benny Joy, Maya Damayanti, Tamyid Syammusa, Nenny Nurlaeni, Anny Yuniarti, Emma Trinurani dan Yuliati Machfud. 2008. Pupuk dan Pemupukan. Jurusan Ilmu Tanah dan Sumber Daya Lahan. Universitas Padjadjaran, Jatinangor.

Tan, K. H. 1995. Dasar-Dasar Kimia Tanah, Terjemahan: Didiek Hadjar Goenadi. Gadjah Mada University Press, Yogyakarta.

Thorbun, C. 1982, Rice Husks as Fuel, PT Tekton Books, Development Tehnology Center - Bandung Institue of Tehnology (DTC-ITB), Bandung.

Tlustos, P., J. Szakova, J. Hruby, I. Hartman, J. Najmanova, J. Nedelnik, D. Pavlikova, M and Batysta. 2006. Removal of AS, Cd, Pb and $\mathrm{Zn}$ from Contaminated Soil by High Biomass Producing Plants. Journal Plant Soil Environmental.

Wahjuni, S dan Kostradiyanti. 2008. Penurunan Angka Peroksida Minyak Kelapa Tradisional dengan Adsorben Arang Sekam Padi IR 64 Yang Diaktifkan Dengan Kalium Hidroksida. Jurusan Kimia FMIPA Universitas Udayana, Bukit Jimbaran. Online: ejournal.unud.ac.id/abstrak/j-kimvol2-no1-sriwahyuni.pdf. (Diakses pada 07 April 2010). 
Winarti. 1997. Evektivitas Arang Sekam Padi pada dalam Meningkatkan $\mathrm{pH}$. Online: pustaka.litbang.deptan.go.id/publikasi/ip03 2104.pdf. (Diakses pada 12 Februari 2010).

Wilkinson. 1977. Chromium. Encyclophedia of Science Technology, MCGraw Hill, New York.

Zulfadli. 1999. Penentuan Daya Sorpsi Zeolit Bayah terhadap Ion-ion Logam Berat. Program Studi Kimia, BKU Kimia Analitik Fakultas MIPA Universitas Padjadjaran, Bandung. Online: ejournal.unpad.ac.id/abstrak/j-kim-vol2no1-zulfadli.pdf. (Diakses pada 12 Februari 2010).

Wilson Boulevard, Suite 500 Arlington, Virgnia 22209 USA.

Bryden, M., Still, D., Scott, P., Hoffa, G., Ogle, D., Bailis, R., and Goyer, K., 2005. Design Principles for Wood Burning Cook Stoves,
Aprovecho Research Center/Shell Foundation/Partnership for Clean Indoor Air, USEPA EPA-402-K-05_004.

CDM, Simplified Project Design Documents for small scale project activities, CDM Cookstove project Kupang 1, Indonesia, 2006

Intergovernmental Panel on Climate Change, "2006 IPPC Guidelines for National greenhouse Inventories", Vol 2, 2006.

GREET Transportation Fuel Cycle Analysis Model, GREET 1.8b, developed by Argonne National Laboratory, Argonne, IL, released May 8, 2008.

http://www.transportation.anl.gov/software/GRE ET/index.html.

\section{Biomasa Energi Data Book,} http://cta.ornl.gov/bedb/appendix_b.shtml. 